\title{
Evaluasi Kinerja Pegawai Terhadap Pelayanan Kepada Masyarakat Di Kecamatan Talang Kelapa Kabupaten Banyuasin
}

\author{
Benny Usman \\ Manajemen, Fakultas Ekonomi Universitas PGRI Palembang \\ email: benny usman@univpgri-palembang.ac.id
}

\begin{abstract}
ABSTRAK
Penelitian ini dilakukan untuk mengetahui kinerja pegawai terhadap pelayanan kepada masyarakat di Kecamatan Talang Kelapa Kabupaten Banyuasin. Metode penelitian yang digunakan dalam penelitian ini yaitu metode penelitian deskriftif kualitatif. Dalam penelitian ini terdapat 2 variabel yang diwakilkan oleh huruf $\mathrm{X}$ dan $\mathrm{Y}$. Pada penelitian ini metode analisa yang digunakan yaitu metode observasi dan wawancara Hasil dari penelitian menunjukan bahwa Kinerja pegawai masih lebih rendah dari pelayanan yang diinginkan masyarakat di Kecamatan Talang Kelapa Kabupaten Banyuasin, karena rata-rata kinerja $(\mathrm{X})$ yang berjumlah 2,56 lebih kecil dibandingkan rata-rata pelayanan $(\mathrm{Y})$ yang berjumlah 3,15 .
\end{abstract}

Kata Kunci : Kinerja dan pelayanan

\section{A. PENDAHULUAN}

Tujuan pembangunan yang telah nyata dalam masyarakat Indonesia adalah meningkatkan mutu pembangunan secara merata keseluruh Indonesia sampai kepelosok-pelosok desa, sehingga pembangunan bisa merata demi tujuan pembangunan Indonesia. Oleh karena itu untuk ikut menyukseskan tujuan pembangunan tersebut, Sumatera Selatan telah membentuk kabupatenkabupaten baru sebagai pusat pemerintahan dan pusat pelayanan kepada masyarakat.

Kecamatan Talang Kelapa Kabupaten Banyuasin sebagai pusat pemerintahan dan pusat pelayanan masyarakat perlu dipacu perkembangannya dengan pembangunan diberbagai bidang. Kantor Kecamatan merupakan sebagai salah satu unit pelayanan dibidang pemerintahan yang merupakan ujung tombak dalam bidang pelayanan pemerintahan dasar diharapkan dapat memberikan pelayanan bagi masyarakat yang bermutu dan sesuai dengan kebutuhan masyarakat.

Unit pelayanan pemerintahan di Kecamatan Talang Kelapa Kabupaten Banyuasin yaitu pusat pelayanan kepada masyarakat diantaranya pelayanan pembuatan kartu tanda penduduk (KTP), surat keterangan bersih diri (SKBD), pengantar surat keterangan catatan kepolisian (SKCK), dan surat keterangan tidak mampu (SKTM).

Berdasarkan Keputusan Menteri Dalam Negeri (Kepmendagri) Nomor 47 Tahun 1999. Tentang pedoman penilaian kerja, perbandingan pegawai dengan masyarakat yakni 6 pegawai berbanding 1.000 masyarakat. Kenyataan dilapangan secara proporsional jumlah PNS yang berjumlah 10 orang dibanding dengan jumlah pegawai honor berjumlah 4 orang dan TKS berjumlah 10 orang 
belum seimbang, sehingga lebih banyaknya pegawai honor dan TKS dalam pelayanan kepada masyarakat dibanding dengan tenaga PNS. Dari segi umur dan pengalaman pegawai honor dan TKS sebagian besar yaitu lulusan SMA, sehingga dalam hal pelayanan kepada masyarakat masih memerlukan bimbingan dari tenaga PNS serta fasilitas-fasilitas pendukung yang ada pada kantor Camat belum memadai. Hal ini menyebabkan kurang optimalnya kemampuan sumber daya pegawai, sehingga terjadi keterlambatan didalam pelayanan pembuatan KTP, SKBD, pengantar SKCK, dan SKTM di Kecamatan Talang Kelapa Kabupaten Banyuasin. Keadaan kinerja sekarang yang sering terjadi keterlambatan penyelesaian surat-surat yang seharusnya sehari menjadi dua atau tiga hari tersebut, membuat peneliti tertarik untuk mengetahui apakah kinerja pegawai terhadap pelayanan kepada masyarakat di Kecamatan Talang Kelapa Kabupaten Banyuasin sudah sesuai dengan harapan yang diinginkan oleh masyarakat.

\section{B. KAJIAN TEORI}

\section{Pengertian dan Fungsi Evaluasi}

Evaluasi adalah kegiatan mengukur dan menilai. Mengukur lebih bersifat kuantitatif, sedangkan menilai lebih besifat kualitatif. Namun secara umum orang hanya mengidentikkan kegiatan evaluasi sama dengan menilai, karena aktivitas mengukur sudah termasuk didalamnya. Dan tidak mungkin melakukan penilaian tanpa didahului oleh kegiatan pengukuran (Arikunto, 2019).

Pengukuran dapat dilakukan dengan cara membandingkan hasil tes terhadap standar yang ditetapkan. Perbandingan yang telah diperoleh kemudian dikualitatifkan sesuai dengan ketentuan yang berlaku.

Evaluasi merupakan bagian yang tidak bisa dipisahkan dari proses pemerintahan. Evaluasi adalah salah satu alat untuk menentukan apakah suatu pemerintahan telah berhasil atau tidak. Evaluasi keterampilan berbahasa umumnya dilakukan dalam dua bentuk yaitu evaluasi secara tertulis (evaluation a acrit) dan evaluasi secara lisan (evaluation a loral).

Dalam proses pemerintahan, terdapat tiga fungsi besar evaluasi. Tagliante, Christine. (2005) menyebutkan "Trois grands functions de evaluation". Tiga fungsi itu adalah :

1) Fungsi Pronostik yaitu tes awal proses pemerintahan untuk mengetahui kondisi obyektif dari pegawai.

2) Fungsi Diagnostik yaitu evaluasi yang menganalisis kemampuan pegawai pada saat berlangsungnya proses pelayanan pemerintahan.

3) Fungsi Sertifikasi yaitu evaluasi yang berguna untuk menyatakan kedudukan atau peringkat seseorang dalam sebuah pemerintahan.

\section{Pengertian Kinerja dan Faktor- Faktor yang Mempengaruhi Kinerja}

Menurut Gibson, dkk (2003) kinerja (performance) adalah hasil yang diinginkan dari perilaku. Kinerja mengarah pada tugas yang dilakukan seseorang dalam memenuhi tuntutan pekerjaannya.

Menurut Murdijanto (2001) menyatakan bahwa kinerja adalah hasil kerja yang dapat dicapai oleh seseorang atau kelompok orang dalam suatu organisasi sesuai dengan wewenang dan tanggung jawab masing-masing dalam rangka upaya mencapai tujuan organisasi 
bersangkutan secara legal, tidak melanggar hukum dan sesuai dengan moral maupun etika.

Kinerja maksudnya yaitu untuk mengukur kerja masing-masing tenaga kerja pegawai dalam mengembangkan kualitas kerja, pembinaan selanjutnya, dan tindakan perbaikan atas pekerjaan yang kurang sesuai dengan deskripsi pekerjaannya, serta untuk keperluan yang berhubungan dengan masalah tenaga kerja pegawai lainnya.

Menurut Dale Furtwengler (2002). Kinerja dipengaruhi oleh beberapa faktor yaitu :

1. Perbaikan Kinerja, kinerja dapat diukur dalam hal, sebagai berikut:

a. Kecepatan yaitu alat pengukuran kinerja yang sangat penting, itu dikarenakan kinerja pegawai harus bebas dari kesalahan dalam melaksanakan pekerjaannya sesuai dengan keahlian dibidang yang kuasainya agar mencapai mass customization yaitu mengadaptasikan jasa untuk memenuhi kebutuhan individual sambil melayani masyarakat setiap harinya.

b. Kualitas yaitu bagian dari kecepatan, kecepatan tanpa kualitas merupakan suatu hal yang sangat sia-sia. Maksudnya yaitu jika salah satu pegawai dalam pelayanan kepada masyarakat terjadi kesalahan dalam penulisan surat, maka surat tersebut tidak bisa diteruskan kepada instansi lain. Masyarakat akan kecewa, dan akan terjadi pembuatan ulang yang memerlukan tambahan jadwal dan biaya ulang. Jadi kualitas merupakan suatu keharusan dalam pengukuran kinerja. c. Layanan yaitu bagian dari kecepatan dan kualitas, layanan yang buruk (selama atau setelah pelayanan) akan menghapuskan manfaat apapun yang dicapai dari kecepatan dan kualitas. Itulah konsep pelanggan internal yaitu orang-orang dalam organisasi yang mengandalkan layanan. Dan seperti halnya pelanggan eksternal yaitu orangorang diluar organisasi yang dilayani.

d. Nilai yaitu kombinasi dari kualitas dan kebutuhan yang memungkinkan masyarakat untuk merasakan bahwa mereka mendapatkan sesuatu yang lebih dari pada yang mereka butuhkan.

\section{Pengembangan Pegawai}

Penilaian kinerja membantu dalam melaksanakan peran berbagai penasihat dan pelatih. Tidak ada pekerjaan yang lebih hebat selain membantu orang lain untuk menjadi terbaik. Untuk melakukan hal tersebut harus diperhatikan sebagai berikut :

a) Melihat kekuatan pegawai dengan sungguh - sungguh.

b) Mendorong pegawai untuk maju.

c) Memberikan wawasan dan alat untuk membantu kemajuan pegawai.

d) Merayakan keberhasilan pegawai.

e) Membantu pekerjaan pegawai pada masa-masa sulit.

\section{Kepuasan Pegawai}

Penilaian kinerja dapat membantu mengantisipasi dan seringkali mencegah ketidakpuasan pegawai. Penilaian kinerja membantu menemukan sikap pegawai terhadap : keanekaragaman, pertumbuhan, tantangan, pembelajaran, partisipasi, 
keamanan, otonomi, uang, kemampuan mereka sendiri.

\section{Keputusan Kompensasi}

Berikut ini cara untuk menggunakan penilaian kinerja untuk mencegah masalah pegawai untuk mengetahui agar memperoleh kompensasi :

a) Selama proses penilaian, pegawai menyepakati arah dan sasaran kinerja serta pengembangan personal.

b) Menyepakati kompensasi di masa mendatang untuk berbagai tingkat pencapaian.

c) Membuat sistem pemantauan yang memungkinkan pegawai memantau kemajuan mereka.

\section{Keterampilan berkomunikasi}

Nilai terbesar dari penilaian sebagai alat komunikasi terletak pada kemampuan untuk membantu menentukan dimana berkomunikasi secara efektif.

\section{Pengertian Pelayanan}

Tjiptono (2009) menyimpulkan bahwa citra kualitas layanan yang baik bukanlah berdasarkan sudut pandang / persepsi penyedia jasa, melainkan berdasarkan sudut pandang / persepsi konsumen. Hal ini disebabkan karena konsumenlah yang mengkonsumsi serta yang menikmati layanan, sehingga merekalah yang seharusnya menentukan kualitas jasa.

Persepsi konsumen terhadap kualitas jasa merupakan penilaian yang menyeluruh terhadap keunggulan suatu jasa layanan. Bagi pelanggan kualitas pelayanan adalah menyesuaikan diri dengan spesifikasi yang dituntut pelanggan. Pelanggan memutuskan bagaimana kualitas yang dimaksud dan apa yang dianggap penting.

Pelanggan mempertimbangkan suatu kualitas pelayanan. Untuk itu, kualitas dapat dideteksi pada persoalan bentuk, sehingga dapat ditemukan :

$>$ Kualitas pelayanan merupakan bentuk dari sebuah janji.

$>$ Kualitas adalah tercapainya sebuah harapan dan kenyataan sesuai komitmen yang telah ditetapkan sebelumnya.

$>$ Kualitas dan integritas merupakan sesuatu yang tidak terpisahkan.

\section{Standar Dalam Pelayanan Kepada Masyarakat}

Standar Pelayanan adalah ukuran yang telah ditentukan sebagai suatu pembakuan Tjiptono (2009) telah berhasil mengindetifikasikan sepuluh faktor atau dimensi utama yang menentukan kualitas jasa, kesepuluh jasa tersebut yaitu :

1. Dapat dipercaya (Reliability). Yaitu mencakup dua hal pokok yaitu :

$>$ Konsistensi Kerja (Performance) dan

- Kemampuan untuk dipercaya (Dependability).

2. Mendengarkan (Responsiveness). Yaitu kemauan atau kesiapan para pegawai untuk memberikan jasa yang dibutuhkan pelanggan.

3. Kemampuan (Competence). Yaitu setiap pegawai dalam pemerintahan jasa tersebut memiliki keterampilan dan pengetahuan yang dibutuhkan agar dapat memberikan jasa tersebut.

4. Jalan Masuk (Access). Yaitu meliputi kemudahan untuk dihubungi dan ditemui. Hal ini 
berarti lokasi, fasilitas jasa yang mudah dijangkau, waktu menunggu yang tidak terlalu lama, saluran komunikasi mudah untuk dihubungi.

5. Rasa Hormat (Courtesy). Yaitu meliputi sikap yang sopan santun, respek, perhatian,dan keramahan para contact personnel (seperti resepsionis, operator telepon, dan sebagainya).

6. Komunikasi (Communication). Yaitu memberikan informasi kepada masyarakat dalam bahasa yang dapat dipahami, serta selalu mendengarkan saran dan keluhan masyarakat.

7. Kepercayaan (Credibility). Yaitu sifat jujur dan dapat dipercaya, kredebilitas mencakup nama kantor, reputasi kantor, karakteristik contact personnel dan interaksi dengan masyarakat.

8. Jaminan Keamanan (Security). Yaitu aman dari bahaya, resiko, keragu-raguan. Aspek ini meliputi keamanan secara fisik, keamanan financial serta kerahasiaan.

9. Mengerti Keinginan Langganan (Understanding Knowing the customer). Yaitu usaha untuk memahami kebutuhan masyarakat.

10. Bukti yang nyata (Tangible). Yaitu bukti fisik dari jasa yang bisa berupa fasilitas fisik, peralatan yang digunakan, dan respresentasi fisik dari jasa.

\section{METODE PENELITIAN}

Metode penelitian yang digunakan yaitu penelitian deskriftif kualitatif yaitu menggambarkan, melukiskan kinerja pegawai terhadap pelayanan kepada masyarakat di Kecamatan Talang Kelapa Kabupaten Banyuasin dengan menggunakan data dalam bentuk dokumentasi, wawancara dan angket.

D. POPULASI DAN SAMPEL

1) Populasi

Populasi adalah sekelompok orang, kejadian atau segala sesuatu yang mempunyai karakteristik tertentu Nur Indriantoro (2009). Populasi didalam penelitian ini adalah staff pegawai honor yang berjumlah 4 orang dan tenaga kerja sukarela (TKS) yang berjumlah 10 orang serta pegawai negeri sipil (PNS) yang berjumlah 10 orang, populasi penelitian berjumlah 24 orang di Kecamatan Talang Kelapa Kabupaten Banyuasin.

\section{2) Sampel}

Sampel adalah bagian dari elemen - elemen yang dimiliki oleh populasi tersebut Nur Indriantoro (2009). Sampel accidental yang akan diambil pada saat penelitian yaitu staff pegawai honor yang berjumlah 4 orang dan tenaga kerja sukarela (TKS) yang berjumlah 10 orang serta pegawai negeri sipil (PNS) yang berjumlah 10 orang di Kecamatan Talang Kelapa Kabupaten Banyuasin bagian administrasi yang hadir pada saat penelitian. Populasi penelitian seluruhnya diambil atau ditetapkan sebagai sampel penelitian, sehingga sampel penelitian berjumlah 24 orang.

\section{E. TEHNIK PENGUMPULAN DATA}

1) Data Primer

Data primer adalah sumber data penelitian yang diperoleh secara langsung dari sumber asli tidak melalui media perantara Nur Indriantoro (2009). Data primer yang diperoleh penulis dengan cara sebagai berikut : 
a. Observasi

Observasi

merupakan

mengumpulkan data dengan mengamati dilapangan dan mencatat pola prilaku staff pegawai honor yang berjumlah 4 orang dan tenaga kerja sukarela (TKS) yang berjumlah 10 orang serta pegawai negeri sipil (PNS) yang berjumlah 10 orang di Kecamatan Talang Kelapa Kabupaten Banyuasin.

b. Wawancara

Wawancara

merupakan

mengumpulkan data dengan melakukan tanya jawab kepada staff pegawai honor yang berjumlah 4 orang dan tenaga kerja sukarela (TKS) yang berjumlah 10 orang serta pegawai negeri sipil (PNS) yang berjumlah 10 orang di Kecamatan Talang Kelapa Kabupaten Banyuasin yang berhubungan dengan penelitian.

c. Angket

Angket merupakan pengumpulan data yang berupa serangkaian pertanyaan tertulis yang diajukan kepada subyek untuk mendapatkan jawaban secara tertulis juga kepada staff pegawai honor yang berjumlah 4 orang dan tenaga kerja sukarela (TKS) yang berjumlah 10 orang serta pegawai negeri sipil (PNS) yang berjumlah 10 orang di Kecamatan Talang Kelapa Kabupaten Banyuasin yang berhubungan dengan penelitian.

2) Data Sekunder

Data sekunder adalah sumber data penelitian yang diperoleh peneliti secara tidak langsung melalui media perantara Nur Indriantoro (2009). Data sekunder diperoleh penulis di Kecamatan Talang Kelapa Kabupaten Banyuasin dengan cara studi dokumentasi seperti struktur organisasi dan kepustakaan lain yang berhubungan dengan penelitian ini.

\section{F. TEHNIK ANALISIS DATA}

Pada penelitian ini teknik analisa data yang digunakan yaitu observasi dan wawancara dengan menggunakan angket. Dalam penelitian ini terdapat 2 variabel yang diwakilkan oleh huruf $X$ dan $Y$, dimana: $X$ merupakan kinerja dan $Y$ pelayanan. Sasaran evaluasi yang digunakan didalam penilaian kinerja yaitu mengenai empat aspek kinerja : kecepatan, kualitas, layanan dan nilai (Dale Furtwengker, 2002).

Menurut Dale Furtwengker (2002) dalam hal kinerja, digunakan skala 4 tingkat (Likert), keempat penilaian diberikan bobot sebagai berikut :

a. Jawaban sering diberi bobot 4

b. Jawaban biasanya diberi bobot 3

c. Jawaban kadang-kadang diberi bobot 2

d. Jawaban jarang diberi bobot 1

Dalam penyederhanaan rumus mencari kinerja dan pelayanan digunakan rumus :

$\bar{X}=\frac{\sum X_{i}}{n} \quad \bar{Y}=\frac{\sum Y_{i}}{n}$

Keterangan :

$\bar{X}=$ Skor rata - rata tingkat kinerja

$\bar{Y}=$ Skor rata-rata tingkat pelayanan

$\mathrm{n}=$ Jumlah responden

\section{G. HASIL PENELITIAN DAN} PEMBAHASAN 
Menurut Soekidjo (2009) Tingkat Kesesuaian Presentase :

$\begin{array}{ll}>85 \%-100 \% & =\text { Sangat Baik } \\ >70 \%-84 \% & =\text { Baik } \\ >55 \%-69 \% & =\text { Cukup } \\ >40 \%-54 \% & =\text { Kurang } \\ >0-39 \% & =\text { Jelek. }\end{array}$

Keterangan :

Tki = Tingkat kesesuaian responden

$\mathrm{Xi}=$ Skor penilaian kinerja

$\mathrm{Yi}=$ Skor penilaian pelayanan

1) Kecepatan Kinerja dan Keandalan Pelayanan

a) Penilaian responden terhadap kinerja pegawai melakukan pekerjaan bagus dalam menyeimbangkan kecepatan dan kualitas kinerja dalam pekerjaannya.

Dari 24 pegawai yang diteliti, hanya 2 pegawai (8,33\%) diantaranya yang menyatakan sering (bobot 4), 4 pegawai $(16,66 \%)$ menyatakan biasanya (bobot 3) dan 18 pegawai (75\%) menyatakan kadang- kadang (bobot 2) dan tidak ada responden yang menyatakan jarang (bobot 1). Berdasarkan hasil penelitian $(2 \times 4)+(4 \times 3)+$ $(18 \times 2)$ diperoleh jumlah bobot 56.

b) Tingkat pelayanan responden terhadap ketepatan keberangkatan pegawai dan waktu datang ke kantor.

Dari 24 pegawai yang diteliti, hanya 10 pegawai $(41,66 \%)$ diantaranya yang menyatakan sangat penting (bobot 4), 14 pegawai $(58,33 \%)$ menyatakan penting (bobot 3) dan tidak ada responden yang menyatakan cukup penting (bobot 2) dan tidak ada responden yang menyatakan tidak penting (bobot 1). Berdasarkan hasil penelitian (10 x 4) $+(14 \times 3)$ diperoleh jumlah bobot 82 .

Dari kedua bobot penilaian diatas diperoleh tingkat kinerja dan pelayanan adalah cukup (Soekidjo : 2009)

$68,29 \%=\frac{56}{82} \times 100 \%$.

Ini dikarenakan peneliti melihat pada saat penelitian kurang disiplinnya pegawai dalam kecepatan kinerja, sehingga mempengaruhi kualitas dari kinerja itu sendiri. Ini disebabkan oleh beberapa faktor yang mempengaruhi diantaranya pegawai melanggar peraturan jam masuk kerja, terutama sebelum dan setelah lebaran atau pada waktu Camat sedang keluar.

c) Penilaian responden terhadap kinerja pegawai menyelesaikan tugas sesuai jadwal.

Dari 24 pegawai yang diteliti, hanya 2 pegawai $(8,33 \%)$ diantaranya yang menyatakan sering (bobot 4), 10 pegawai $(41,66 \%)$ menyatakan biasanya (bobot 3) dan 12 pegawai (50\%) menyatakan kadang-kadang (bobot 2) dan tidak ada responden yang menyatakan jarang (bobot 1). Berdasarkan hasil penelitian $(2 \times 4)+(10 \times 3)$ $+(12 \times 2)$ diperoleh jumlah bobot 62.

d) Tingkat pelayanan responden terhadap pelayanan yang ramah selalu siap menolong.

Dari 24 pegawai yang diteliti, hanya 12 pegawai (50\%) diantaranya yang menyatakan sangat penting (bobot 4), 12 pegawai $(50 \%)$ menyatakan penting (bobot 3) dan tidak ada responden yang menyatakan cukup penting (bobot 2) dan tidak ada responden yang menyatakan 
tidak penting (bobot 1). Berdasarkan hasil penelitian (12 $\times 4)+(12 \times 3)$ diperoleh jumlah bobot 84 .

Dari kedua bobot penilaian diatas diperoleh tingkat kinerja dan pelayanan adalah baik (Soekidjo : 2009)

$73,80 \%=\frac{62}{84} \times 100 \%$.

Peneliti melihat dalam pelayanan yang diberikan pegawai Kecamatan memang terkesan ramah dan selalu siap menolong, sehingga masyarakat Sungai Pinang dalam urusan suratmenyurat di Kantor Camat tidak terlihat dikecewakan.

e) Penilaian responden terhadap kinerja pegawai mencari cara untuk menyelesaikan pekerjaan rutin dengan lebih cepat.

Dari 24 pegawai yang diteliti, tidak ada responden yang menyatakan sering (bobot 4), 12 pegawai $(50 \%)$ menyatakan biasanya (bobot 3) dan 12 pegawai $(50 \%)$ menyatakan kadang-kadang (bobot 2) dan tidak ada responden yang menyatakan jarang (bobot 1). Berdasarkan hasil penelitian (12 x 3$)+(12 \times 2)$ diperoleh jumlah bobot 60 .

f) Tingkat pelayanan responden terhadap prosedur penerimaan pelayanan kepada masyarakat yang cepat dan tepat.

Dari 24 pegawai yang diteliti, hanya 12 pegawai (50\%) diantaranya yang menyatakan sangat penting (bobot 4), 12 pegawai $(50 \%)$ menyatakan penting (bobot 3) dan tidak ada responden yang menyatakan cukup penting (bobot 2) dan tidak ada responden yang menyatakan tidak penting (bobot 1).
Berdasarkan hasil penelitian (12 $x 4)+(12 \times 3)$ diperoleh jumlah bobot 84. Dari kedua bobot penilaian diatas diperoleh tingkat kinerja dan pelayanan adalah baik (Soekidjo : 2009)

$71,42 \%=\frac{60}{84} \times 100 \%$.

Peneliti menilai prosedur penerimaan pelayanan kepada masyarakat yang cepat dan tepat memang dapat dibenarkan, peneliti melihat usaha pegawai dalam mencari cara untuk menyelesaikan pekerjaan rutin dengan lebih cepat, untuk itu dalam pertanyaan ini mendapat nilai persentase baik.

2) Kualitas Kinerja dan Keyakinan Pelayanan

a) Penilaian responden terhadap kinerja pegawai bangga terhadap pekerjaannya.

Dari 24 pegawai yang diteliti, hanya 4 pegawai $(16,66 \%)$ diantaranya yang menyatakan sering (bobot 4), 10 pegawai $(41,66 \%)$ menyatakan biasanya (bobot 3) dan 10 pegawai $(41,66 \%)$ menyatakan kadangkadang (bobot 2) dan tidak ada responden yang menyatakan jarang (bobot 1). Berdasarkan hasil penelitian $(4 \times 4)+(10 \times 3)$ $+(10 \times 2)$ diperoleh jumlah bobot 66.

b) Tingkat pelayanan responden terhadap kemampuan pegawai untuk cepat tanggap dalam menghadapi masalah yang timbul.

Dari 24 pegawai yang diteliti, hanya 2 pegawai (8,33\%) diantaranya yang menyatakan sangat penting (bobot 4), 20 pegawai $(83,33 \%)$ menyatakan penting (bobot 3 ) dan 2 pegawai 
$(8,33 \%) \quad$ diantaranya yang menyatakan cukup penting (bobot 2) dan tidak ada responden yang menyatakan tidak penting (bobot 1). Berdasarkan hasil penelitian $(2 \mathrm{x}$ $4)+(20 \times 3)+(2 \times 2)$ diperoleh jumlah bobot 72 .

Dari kedua bobot penilaian diatas diperoleh tingkat kinerja dan pelayanan adalah sangat baik (Soekidjo : 2009)

$91,66 \%=\frac{66}{72} \times 100 \%$.

Tingkat kinerja pegawai bangga terhadap pekerjaannya dapat dilihat peneliti dalam keseriusan pegawai untuk cepat tanggap dalam menghadapi masalah yang timbul, sehingga tingkat keseuaian pada daftar pertanyaan ini sangat baik.

c) Penilaian responden terhadap kinerja pegawai melakukan pekerjaannya dengan benar sejak pertama kalinya.

Dari 24 pegawai yang diteliti, hanya 1 pegawai $(4,16 \%)$ diantaranya yang menyatakan sering (bobot 4), 5 pegawai $(20,83 \%)$ menyatakan biasanya (bobot 3) dan 18 pegawai (75\%) menyatakan kadang-kadang (bobot 2) dan tidak ada responden yang menyatakan jarang (bobot 1). Berdasarkan hasil penelitian $(1 \times 4)+(5 \times 3)+$ $(18 \times 2)$ diperoleh jumlah bobot 55.

d) Tingkat pelayanan responden terhadap kemampuan pegawai cepat tanggap terhadap keluhan yang disampaikan masyarakat.

Dari 24 pegawai yang diteliti, hanya 2 pegawai $(8,33 \%)$ diantaranya yang menyatakan sangat penting (bobot 4), 12 pegawai $(50 \%)$ menyatakan penting (bobot 3) dan 10 pegawai $(41,66 \%)$ diantaranya yang menyatakan cukup penting (bobot 2) dan tidak ada responden yang menyatakan tidak penting (bobot 1). Berdasarkan hasil penelitian $(2 \mathrm{x}$ $4)+(12 \times 3)+(10 \times 2)$ diperoleh jumlah bobot 64 .

Dari kedua bobot penilaian diatas diperoleh tingkat kinerja dan pelayanan adalah sangat baik (Soekidjo : 2009)

$85,93 \%=\frac{55}{64} \times 100 \%$.

Kinerja pegawai melakukan pekerjaannya dengan benar sejak pertama kalinya dan kemampuan pegawai cepat tanggap terhadap keluhan yang disampaikan masyarakat merupakan sesuatu yang diterapkan oleh kantor Kecamatan Sungai Pinang yang terus dihimbau Camat agar kesan kantor Kecamatan dapat memberikan rasa kepuasan masyarakat.

e) Penilaian responden terhadap kinerja pegawai mencari cara untuk memperbaiki kualitas pekerjaannya.

Dari 24 pegawai yang diteliti, hanya 2 pegawai (8,33\%) diantaranya yang menyatakan sering (bobot 4), 10 pegawai $(41,66 \%)$ menyatakan biasanya (bobot 3) dan 12 pegawai (50\%) menyatakan kadang-kadang (bobot 2) dan tidak ada responden yang menyatakan jarang (bobot 1). Berdasarkan hasil penelitian $(2 \times 4)+(10 \times 3)$ $+(12 \times 2)$ diperoleh jumlah bobot 62.

f) Tingkat pelayanan responden terhadap pegawai memberikan 
informasi yang jelas, mudah dimengerti.

Dari 24 pegawai yang diteliti, hanya 2 pegawai (8,33\%) diantaranya yang menyatakan sangat penting (bobot 4), 15 pegawai $(62,50 \%)$ menyatakan penting (bobot 3) dan 7 pegawai $(29,16 \%)$ diantaranya yang menyatakan cukup penting (bobot 2) dan tidak ada responden yang menyatakan tidak penting (bobot 1). Berdasarkan hasil penelitian $(2 \mathrm{x}$ $4)+(15 \times 3)+(7 \times 2)$ diperoleh jumlah bobot 67 .

Dari kedua bobot penilaian diatas diperoleh tingkat kinerja dan pelayanan adalah sangat baik (Soekidjo : 91)

$92,53 \%=\frac{62}{67} \times 100 \%$.

Kinerja pegawai mencari cara untuk memperbaiki kualitas pekerjaannya diantaranya dengan cara merencanakan semua keperluan pelaksanaan tugas jauh sebelumnya untuk tujuan memberikan informasi yang jelas, mudah dimengerti bagi masyarakat.

3) Layanan Kinerja dan Empati Pelayanan

a) Penilaian responden terhadap kinerja tindakan pegawai dapat mengindikasikan pemahaman pentingnya melayani, baik pada masyarakat internal maupun eksternal.

Dari 24 pegawai yang diteliti, tidak ada responden yang menyatakan sering (bobot 4), 14 pegawai $(58,33 \%)$ menyatakan biasanya (bobot 3) dan 10 pegawai $(41,66 \%)$ menyatakan kadang-kadang (bobot 2) dan tidak ada responden yang menyatakan jarang (bobot 1). Berdasarkan hasil penelitian (14 $x 3)+(10 \times 2)$ diperoleh jumlah bobot 62 .

b) Tingkat pelayanan responden terhadap pengetahuan dan kemampuan para pegawai dalam menyelesaikan keluhan masyarakat.

Dari 24 pegawai yang diteliti, hanya 2 pegawai (8,33\%) diantaranya yang menyatakan sangat penting (bobot 4), 22 pegawai $(91,66 \%)$ menyatakan penting (bobot 3) dan tidak ada responden yang menyatakan cukup penting (bobot 2) dan tidak ada responden yang menyatakan tidak penting (bobot 1). Berdasarkan hasil penelitian $(2 \mathrm{x}$ $4)+(22 \times 3)$ diperoleh jumlah bobot 74 .

Dari kedua bobot penilaian diatas diperoleh tingkat kinerja dan pelayanan adalah baik (Soekidjo : 2009)

$83,78 \%=\frac{62}{74} \times 100 \%$.

Kinerja tindakan pegawai dapat mengindikasikan pemahaman pentingnya melayani yaitu dengan cara mendokumentasikan contohcontoh penting tentang prestasi kerja yang baik dan yang tidak baik agar tercipta pengetahuan dan kemampuan para pegawai dalam menyelesaikan keluhan masyarakat.

c) Penilaian responden terhadap kinerja pegawai menunjukan keinginannya untuk melayani orang lain dengan baik.

Dari 24 pegawai yang diteliti, 4 pegawai $(16,66 \%) \quad$ yang menyatakan sering (bobot 4), 20 pegawai $(83,66 \%)$ menyatakan biasanya (bobot 3) dan tidak ada 
responden yang menyatakan kadang-kadang (bobot 2) dan jarang (bobot 1). Berdasarkan hasil penelitian $(4 \times 4)+(20 \times 3)$ diperoleh jumlah bobot 76 .

d) Tingkat pelayanan responden terhadap melakukan komunikasi yang efektif dengan masyarakat. Dari 24 pegawai yang diteliti, hanya 4 pegawai $(16,66 \%)$ diantaranya yang menyatakan sangat penting (bobot 4), 20 pegawai $(83,33 \%)$ menyatakan penting (bobot 3) dan tidak ada responden yang menyatakan cukup penting (bobot 2) dan tidak penting (bobot 1). Berdasarkan hasil penelitian $(4 \times 4)+(20 \times 3)$ diperoleh jumlah bobot 76 .

Dari kedua bobot penilaian diatas diperoleh tingkat kinerja dan pelayanan adalah sangat baik (Soekidjo : 2009)

$$
100 \%=\frac{76}{76} \times 100 \%
$$

Ini dikarenakan peneliti melihat pada saat penelitian bahwa pegawai selalu melayani orang lain dengan baik dan juga selalu melakukan komunikasi yang efektif dengan masyarakat. Sehingga dalam pertanyaan ini tingkat kesesuaian sangat baik.

e) Penilaian responden terhadap kinerja pegawai merespon masyarakat dengan tepat waktu. Dari 24 pegawai yang diteliti, tidak ada responden yang menyatakan sering (bobot 4), 12 pegawai $(50 \%)$ menyatakan biasanya (bobot 3) dan 12 pegawai (50\%) yang menyatakan kadang-kadang (bobot 2) dan tidak ada responden yang menyatakan jarang (bobot 1). Berdasarkan hasil penelitian (12 $x 3)+(12 \times 2)$ diperoleh jumlah bobot 60 . f) Tingkat pelayanan responden terhadap memberikan perhatian secara individu kepada masyarakat.

Dari 24 pegawai yang diteliti, hanya 2 pegawai (8,33\%) diantaranya yang menyatakan sangat penting (bobot 4), 17 pegawai $(70,83 \%)$ menyatakan penting (bobot 3) dan 5 pegawai $(20,83 \%)$ yang menyatakan cukup penting (bobot 2) dan tidak ada responden yang menyatakan tidak penting (bobot 1). Berdasarkan hasil penelitian (2 $\times 4)+(17 \times 3)+(5 \times 2)$ diperoleh jumlah bobot 69 .

Dari kedua bobot penilaian diatas diperoleh tingkat kinerja dan pelayanan adalah sangat baik (Soekidjo : 91)

$86,95 \%=\frac{60}{69} \times 100 \%$.

Melakukan pemeriksaan pelaksanaan kerja secara langsung merupakan yang dilakukan Camat dalam melihat kinerja pegawai dalam merespon masyarakat dengan tepat waktu. Sehingga dalam pertanyaan ini tingkat kesesuaian sangat baik.

4) Nilai Kinerja dan Berwujud Pelayanan

a) Penilaian responden terhadap kinerja tindakan pegawai mengindikasikan pemahaman mengenai konsep nilai.

Dari 24 pegawai yang diteliti, tidak ada responden yang menyatakan sering (bobot 4), 12 pegawai $(50 \%)$ menyatakan biasanya (bobot 3) dan 6 pegawai (25\%) yang menyatakan kadang-kadang (bobot 2) dan 6 pegawai $(25 \%)$ yang menyatakan jarang (bobot 1). Berdasarkan hasil penelitian $(12 \times 3)+(6 \times 2)$ 
$+(6 \times 1)$ diperoleh jumlah bobot 54.

b) Tingkat pelayanan responden terhadap kebersihan dan kerapian kantor dan pegawai.

Dari 24 pegawai yang diteliti, hanya 2 pegawai $(8,33 \%)$ diantaranya yang menyatakan sangat penting (bobot 4), 17 pegawai $(70,83 \%)$ menyatakan penting (bobot 3) dan 5 pegawai $(20,83 \%)$ yang menyatakan cukup penting (bobot 2) dan tidak ada responden yang menyatakan tidak penting (bobot 1). Berdasarkan hasil penelitian $(2 \mathrm{x}$ $4)+(17 \times 3)+(5 \times 2)$ diperoleh jumlah bobot 69 .

Dari kedua bobot penilaian diatas diperoleh tingkat kinerja dan pelayanan adalah baik (Soekidjo : 2009)

$78,26 \%=\frac{54}{69} \times 100 \%$.

Memeriksa ruangan kerja sebelum melaksanakan aktivitas merupakan sesuatu yang dilakukan pegawai dalam dalam menjaga kebersihan dan kerapian kantor, Sehingga dalam pertanyaan ini tingkat kesesuaian baik.

c) Penilaian responden terhadap kinerja nilai merupakan suatu yang dipertimbangkan oleh pegawai dalam pengambilan keputusan.

Dari 24 pegawai yang diteliti, 10 pegawai $(41,66 \%) \quad$ yang menyatakan sering (bobot 4), 10 pegawai $(41,66 \%)$ menyatakan biasanya (bobot 3) dan 4 pegawai $(16,66 \%) \quad$ yang menyatakan kadang-kadang (bobot 2) dan tidak ada responden yang menyatakan jarang (bobot 1). Berdasarkan hasil penelitian $(10 \times 4)+(10 \times 3)$ $+(4 \times 2)$ diperoleh jumlah bobot 78.

d) Tingkat pelayanan responden terhadap bertanggung jawab terhadap keamanan dan kenyamanan masyarakat.

Dari 24 pegawai yang diteliti, hanya 12 pegawai (50\%) diantaranya yang menyatakan sangat penting (bobot 4), 12 pegawai $(50 \%)$ menyatakan penting (bobot 3 ) dan tidak ada responden yang menyatakan cukup penting (bobot 2) dan tidak penting (bobot 1). Berdasarkan hasil penelitian $(12 \times 4)+(12 \times 3)$ diperoleh jumlah bobot 84 .

Dari kedua bobot penilaian diatas diperoleh tingkat kinerja dan pelayanan adalah baik (Soekidjo : 2009)

$82,85 \%=\frac{78}{84} \times 100 \%$.

Memeriksa ruangan kerja untuk menjamin keamanan adalah pekerjaan lain Camat yang adakalanya diharapkan dari masyarakat untuk melindungi masyarakat dari tindakan sewenang-wenang pegawai yang menyalahi prosedur yang ada, oleh karena itu dari daftar pertanyaan ini mendapat tingkat kesesuaian persentase baik.

e) Penilaian responden terhadap kinerja pegawai jika tidak menemukan nilai pada suatu usaha, membuat pihak berwenang menyadari masalah yang dihadapinya.

Dari 24 pegawai yang diteliti, tidak ada responden yang menyatakan sering (bobot 4), 8 pegawai $(33,33 \%)$ menyatakan biasanya (bobot 3) dan 6 pegawai $(25 \%)$ yang menyatakan 
kadang-kadang (bobot 2) dan 10 pegawai $(41,66 \%) \quad$ yang menyatakan jarang (bobot 1 ). Berdasarkan hasil penelitian $(8 \mathrm{x}$ $3)+(6 \times 2)+(10 \times 1)$ diperoleh jumlah bobot 46 .

f) Tingkat pelayanan responden terhadap penataan eksterior dan interior kantor yang baik.

Dari 24 pegawai yang diteliti, hanya 10 pegawai $(41,66 \%)$ diantaranya yang menyatakan sangat penting (bobot 4), 14 pegawai (58,33\%) menyatakan penting (bobot 3) dan tidak ada responden yang menyatakan cukup penting (bobot 2) dan tidak penting (bobot 1). Berdasarkan hasil penelitian $(10 \times 4)+(14 \times 3)$ diperoleh jumlah bobot 82 .

Dari kedua bobot penilaian diatas diperoleh tingkat kinerja dan pelayanan adalah cukup (Soekidjo : 2009)

$56,09 \%=\frac{46}{82} \times 100 \%$.

Ini dikarenakan pada saat pegawai melakukan pelayanan terjadi lambatnya penyelesaian pelayanan tersebut dan dari segi penatan eksterior dan interior karena kecamatan ini adalah kecamatan baru dan gedung kantor yang baru dan terlihat masih memerlukan ruangan baru lain sehingga terlihat penataan tersebut kurang baik

\section{J. KESIMPULAN DAN SARAN}

1) Kesimpulan

Berdasarkan penelitian yang telah dilakukan, maka dapat disimpulkan sebagai berikut :

a) Kinerja pegawai masih lebih rendah dari pelayanan yang diinginkan masyarakat di Kecamatan Talang Kelapa
Kabupaten Banyuasin, karena rata-rata kinerja $(\mathrm{X})$ yang berjumlah 2,56 lebih kecil dibandingkan rata-rata pelayanan (Y) yang berjumlah 3,15.

b) Kinerja yang masih rendah adalah sebagai berikut :

1. Kecepatan.

Kinerja yang masih kurang dan masih ada masalah pada aspek kecepatan yaitu pada pertanyaan pegawai melakukan pekerjaan bagus dalam menyeimbangkan

kecepatan kualitas kinerja dan kualitas kinerja dalam pekerjaannya dengan jumlah rata-rata 2,33 lebih kecil dibandingkan dengan jumlah rata-rata kinerja (X) yang berjumlah 2,56. Dan pada pertanyaan pegawai mencari cara untuk menyelesaikan pekerjaan rutin dengan lebih cepat dengan jumlah rata - rata 2,50 lebih kecil dibandingkan dengan jumlah rata-rata kinerja $(\mathrm{X})$ yang berjumlah 2,56.

2. Kualitas

Kinerja yang masih kurang dan masih ada masalah pada aspek kualitas yaitu pada pertanyaan pegawai melakukan pekerjaannya dengan benar sejak pertama kalinya dengan jumlah rata-rata 2,29 lebih kecil dibandingkan dengan jumlah rata-rata kinerja (X) yang berjumlah 2,56 .

3. Nilai. 
Kinerja yang masih kurang dan masih ada masalah pada aspek nilai yaitu pada pertanyaan tindakan pegawai mengindikasikan pemahaman mengenai konsep nilai dengan jumlah rata-rata 2,25 lebih kecil dibandingkan dengan jumlah rata-rata kinerja $(\mathrm{X})$ yang berjumlah 2,56. Dan pada pertanyaan jika pegawai tidak menemukan nilai pada suatu usaha, ia akan membuat pihak berwenang menyadari masalah yang dihadapinya dengan jumlah rata-rata 1,92 lebih kecil dibandingkan dengan jumlah rata-rata kinerja (X) yang berjumlah 2,56.

c) Pelayanan yang masih rendah yaitu sebagai berikut :

$>$ Keyakinan

Pelayanan yang masih kurang dan masih ada masalah pada aspek keyakinan yaitu pada pertanyaan kemampuan pegawai untuk cepat tanggap dalam menghadapi masalah yang timbul dengan jumlah rata-rata 3,00 lebih kecil dibandingkan dengan jumlah rata-rata pelayanan (Y) yang berjumlah 3,15. Dan pada pertanyaan kemampuan pegawai cepat tanggap terhadap keluhan yang disampaikan masyarakat dengan jumlah rata-rata 2,67 lebih kecil dibandingkan dengan jumlah rata-rata pelayanan (Y) yang berjumlah 3,15. Serta pada pertanyaan pegawai memberikan informasi yang jelas, mudah dimengerti dengan jumlah rata-rata 2,79 lebih kecil dibandingkan dengan jumlah rata-rata pelayanan (Y) yang berjumlah 3,15.

Empati.

Pelayanan yang masih kurang dan masih ada masalah pada aspek empati yaitu pada pertanyaan pengetahuan dan kemampuan para pegawai dalam menyelesaikan keluhan masyarakat dengan jumlah rata-rata 3,08 lebih kecil dibandingkan dengan jumlah rata-rata pelayanan (Y) yang berjumlah 3,15. Dan pada pertanyaan memberikan perhatian secara individu kepada masyarakat dengan jumlah rata-rata 2,87 lebih kecil dibandingkan dengan jumlah rata-rata pelayanan $(\mathrm{Y}) \quad$ yang berjumlah 3,15.

\section{2) Saran}

Berdasarkan kesimpulan diatas, maka dapat dikemukakan beberapa saran sebagai berikut:

a) Pegawai selalu melayani masyarakat dengan baik dan juga selalu melakukan komunikasi yang efektif dengan masyarakat agar dapat dipertahankan supaya terciptanya profesionalitas untuk lebih majunya pemerintahan di Kecamatan Talang Kelapa Kabupaten Banyuasin.

b) Penyelesaian pelayanan di Kecamatan lebih diperhatikan pegawai agar tidak terjadi keterlambatan lagi di dalam pelayanan dan dari segi 
penataan eksterior dan interior lebih ditata agar terjadinya kenyamanan.

c) Lebih memperhatikan ketepatan waktu pegawai datang dan pulang kekantor, karena hal ini merupakan unsur utama yang diinginkan oleh masyarakat dan membawa image yang baik bagi kecamatan

d) Pegawai yang belum melaksanakan kinerja secara optimal agar diberikan pendidikan dan pelatihan.

e) Diadakan studi banding masalah kinerja dan pelayanan ke Kecamatan lain.

\section{DAFTAR PUSTAKA}

Arikunto, Suharsimi. 2019. Dasardasar Evaluasi Pendidikan (Edisi 3). Penerbit: Bumi Aksara-Jakarta

Boston Gibson. 2003. Organisasi : Perilaku, struktur, proses, Jakarta, Binarupa Akasara.
Furtwengler, Dale. 2002. Penilaian Kinerja: Menguasai Keahlian Yang Anda Perlukan Dalam 10 menit. Penerbit Andi. Yogyakarta

Indriantoro, Nur., \& Supomo, Bambang. 2009. Metodelogi Penelitian Bisnis. Yogyakarta : BPFE - Yogyakarta.

Tagliante, Christine. 2005. L'Evaluation et Le Cadre Européen Commun. Paris : CLE International

Murdjianto. 2001. Manajemen Sumber Daya Manusia. Bina Atmaja : Bandung

Notoatmodjo, Soekidjo. 2009. Pengembangan Sumber Daya Manusia. PT. Rineka Cipta, Jakarta.

Tjiptono, Fandy. 2009. Strategi Pemasaran Jasa. Yogyakarta

Zeithaml, Bitner. 2006. Delivering Quality Service: Balancing Custumer Perception and Expectations. New York: The Freev Press. 